\title{
Observations of market power in Finnish food retailing
}

\author{
Jyrki Niemi ja Liu Xing \\ MTT Taloustutkimus, Luutnantintie 13,00410 Helsinki,jyrki.niemi@mtt.fi,xing.liu@mtt.fi
}

\section{Tiivistelmä}

Elintarvikkeiden hintataso ja hintojen kehitys herättävät aika ajoin keskustelua ja kysymyksiä kotimaisen elintarvikeketjun toimivuudesta ja kilpailullisuudesta. Hintakehityksen lisäksi keskustelua herättää kuluttajan maksaman hinnan jakautuminen elintarvikeketjun sisällä, mikä antaa aiheen tarkastella elintarvikeketjun eri osien keskinäisiä voimasuhteita ja näiden merkitystä kilpailulle, elintarvikeketjussa tapahtuvalle tulonjaolle ja elintarvikkeiden hinnanmuodostukselle. Tässä tutkimuksessa on analysoitu tilastollisin välinein suomalaisten elintarvikemarkkinoiden toimivuutta ja kilpailullisuutta elintarvikeketjun eri osissa ulottuen aina alkutuotannosta vähittäiskauppaan.

Pitkän aikavälin tilastot osoittavat selkeästi, että väliportaiden osuus ruuan kuluttajahinnasta on kasvanut 2000-luvulla, kun samaan aikaan maataloustuottajien ruuan loppuhinnasta saama osuus on laskenut. Hallitsevan markkina-aseman hyödyntäminen mainitaan usein selityksenä laskeviin tuottajahintamarginaaleihin. Elintarviketeollisuus ja etenkin vähittäiskauppa ovat yhdistyneet kovaa vauhtia fuusioiden, strategisten liittoutumien ja muiden yrityskokoa suurentavien järjestelyjen kautta. Suomessa vähittäiskauppasektorin keskittyminen on ollut erityisen nopeaa. Kaksi johtavaa elintarvikkeiden ja päivittäistavaratuotteiden vähittäismyyntiketjua kasvattivat markkinaosuuttaan 55 prosentista vuonna 1990 yli 75 prosenttiin vuonna 2008.

Markkinavoiman väärinkäytön todistaminen on kuitenkin empiirisesti melko vaikeaa, sillä suuri markkinaosuus ei välttämättä tarkoita suurta markkinavoimaa. Kasvavaa eroa elintarvikkeiden vähittäismyynti- ja tuottajahintojen välillä selittävät $\mathrm{mm}$. elintarvikehygienian tiukentuneet standardit, tuottavuuserot ketjun eri osissa, maatalouspolitiikan muutokset ja kansainvälisen kaupan vapautuminen. Kaikkia mahdollisia selityksiä olisi pystyttävä tarkastelemaan yhdessä, jotta ymmärrettäisiin paremmin elintarvikeketjun dynamiikkaa.

Tässä tutkimuksessa ostajapuolen markkinavoiman mahdollista olemassaoloa on testattu Lloydin ym. 2009 kehittämällä ekonometrisella mallilla, joka hyödyntää elintarvikkeiden ja maataloustuotteiden hintojen, elintarvikkeiden kysynnän sekä tuotanto- ja markkinakustannusten välisiä reaktioita. Tutkimuksessa on estimoitu elintarvikemarkkinoita kuvaava ekonometrinen malli ja yhteisintegroituvuuteen perustuvan virheenkorjausmallin avulla on arvioitu tuottajahintojen ja muiden kustannustekijöiden muutosten siirtymistä elintarvikkeiden kuluttajahintoihin.

Estimoidut empiiriset tulokset osoittavat, että Suomen elintarvikemarkkinoilla vallitsee epätäydellinen kilpailu, toisin sanoen vähittäiskaupalla on markkinavoimaa suhteessa elintarviketeollisuuteen ja maataloustuotantoon. Tulosten mukaan vähittäiskaupalla on siten mahdollisuus hyödyntää jossain määrin niin sanottua mark up- hinnoittelua eli osa hinnasta voidaan potentiaalista markkinavoimaa käyttämällä ohjata kaupan tulokseksi, mikäli kuluttajien hintajousto on sopiva, eikä hinta ole pakollinen kilpailukeino.

Asiasanat: elintarvikemarkkinat, kuluttajahinta, tuottajahinta, vähittäiskauppa, keskittyminen, markkinavoima 


\section{Introduction}

Market power and competition policy in food supply chains has emerged as an important economic issue and a highly sensitive item on the policy agenda all around the world. Claims that large retailers and food companies are depressing farm prices because of their market power have been made in many countries around the world (Swinnen ans Vandeplas 2009).

Clearly, the food industry, and the retail sector in particular, have consolidated through mergers and acquisitions and strategic alliances. Retail buying is becoming more and more concentrated, in part because retailers have become very large sellers and in part because retailers combine their buying activities (Dobson et al. 2003). In Finland, the increased concentration of the retail sector, with fewer outlets and the growth of the large supermarket chains, has been particularly fast. The two leading Finnish retail chains of food and daily goods increased their market share from 55 per cent in 1990 to nearly 75 per cent in 2008 (Niemi and Ahlstedt 2009).

Abuse of a dominant position in the market is therefore frequently mentioned as an explanation for the decreasing producer price margins in Finland. Yet, the widening price spreads between retail and producer prices of food are not themselves indicative of imperfect competition, since competitive factors, such as rising marketing costs may be responsible. The analysis by Kuosmanen and Niemi (2009) lists many plausible reasons for the observed growth in price spreads, including 1) increased degree of processing, 2) better food hygiene, 3) differences in productivity growth across sectors, 4) agricultural policy reforms, 5) international trade, and 6) imperfect competition. The follow-up study by Kuosmanen, Niemi \& Sipiläinen (2009) suggests that differences in productivity growth in agriculture, food processing and retail sector explain most of the observed patterns in price margins.

Generally two approaches have been taken in identifying and estimating market power: structure-conduct-performance (SCP) studies and new empirical industrial organization (NEIO) studies. SCP studies have mainly used cross-sectional data to estimate the relationship between price-cost margins and concentration ratios to draw inferences about the presence of market power, while NEIO studies have generally tended to find some statistical evidence of market power by focussing on the determinants of the gap between price and the marginal cost (Wohlgenant 2001).

There are number of empirical studies relating retail prices to concentration ratios of retailers. However, they arrive at very diverging conclusions. On the one hand, Hall et al. (1979) and various studies by Cotterill (Cotterill 1986; Cotterill and Harper 1995; Cotterill 1999) find that there is a positive correlation between retail concentration and food prices. On the other hand, Kauffmann and Handy (1989), and Binkley and Connor (1998) find a negative or insignificant correlation between concentration and food prices. Likewise, Binkley et al. (2002) find "little compelling evidence that consolidated markets engage in non-competitive pricing behaviour."

Following an approach used by Lloyd et al (2009), this paper measures market power in the Finnish food retail industry. It offers a 'first-filter' test of price data that may be used as part of the preliminary analyses into the presence of buyer power in food markets. The model also serves as a useful device for characterising how prices are transmitted in food market, albeit in simplified form. Furthermore, it forms the basis for determining the appropriate econometric approach and the interpretation of the key variables used to identify the existence of possible oligopoly or oligopsony power.

\section{Recent trends in Finnish food retailing}

The operating environment of Finnish food economy changed radically in 1995 when Finland joined the EU. The retail price of food fell, on average, by $11 \%$ in 1995 , even though the value added tax was raised. The reduction was caused by the decrease in the producer prices to the same level as in the other Member States and liberalisation of imports from the EU countries. The prices of cereal and meat products fell the most dramatically (Niemi and Ahlstedt 2009).

The EU membership also clearly reinforced the position of retail sector in the food chain relative to the domestic raw material production and food industry. The retail sector is able to take advantage of the competition between the domestic food companies and foreign ones. Structural changes in the retail trade are directly influencing the market opportunities of food producers in four ways: through (1) concentration, (2) chaining, (3) discount stores and (4) private labels. As a result of the concentration in the retail trade sector, very large units, hypermarkets, have conquered market shares from smaller units. From 1995 until 2007 the share of hypermarkets in the sales grew from 15 to $25 \%$ and the share of large supermarkets from $20 \%$ to as high as $33 \%$. 
In recent years significant reorganisations have taken place among the largest chains. The competition for the market in groceries and daily consumer good is more and more clearly a case between two main players. The market share of the S Group has increased rapidly over the past years. In 2008, the S Group managed to raise its market share again reaching $42.4 \%$. The share of the K Group has been diminishing in the past few years, and as a result, the market share of $\mathrm{K}$ Group decreased to $33.7 \%$ in 2008 . The share of the third largest chain Tradeka also experienced a fall in its market share from $11.9 \%$ in $2006-07$ to $11.3 \%$ in 2008 . The largest chain in the category of other companies is the German discount giant Lidl, which has spread rapidly on the Finnish market. In 2008 the share of Lidl was estimated at $5.1 \%$, which was slightly higher than the year before, when it was $4.7 \%$.

The large food chains consist of independent retail operators who compete on the local markets, while the wholesale and purchasing operations within the chain are strongly concentrated. Large chains take advantage of their negotiation power in their supply contracts with food processing companies. In both leading chains the share of the concentrated purchases has risen to more than $80 \%$, leaving very little room for local purchases by the retail operators. Of local foods mainly some bakery products, fresh meat and fresh cheeses have gained access to the shelves (Niemi and Ahlstedt 2009).

\section{Theoretical model and empirical implementation}

As mentioned in the introduction, this study utilizes a theoretical approach used by Lloyd et al (2009) exploiting the presence of exogenous shocks in order to identify the presence of buyer power on both upstream and downstream prices. The detection of buyer power simply depends on how the incidence of shocks affects both sets of prices. While the simplicity of the approach does not allow us to retrieve an empirical estimate of the degree of buyer power, the trade-off does circumvent some of the obstacles inherent in the estimation of structural econometric modelling and the difficulties associated with the interpretation of estimated conjectures. More specifically, in framework by Lloyd's et al. (2009), the difference (or spread) between prices at different marketing levels can be attributed solely to marketing costs under competitive conditions.

If buyer power exists then the spread between retail and producer supply prices behaves differently since price setting by the sector with buyer power will be reflected in the mark down that the firms can earn, and so affects the spread. Hence, where buyer power exists, market shocks have a differential impact at each stage in the marketing chain and thus determine the behaviour of the spread between prices at different vertical levels in addition to marketing costs. In effect, shocks to the underlying supply and demand functions are mediated through buyer power parameters and thus give rise to predictable effects on the spread. In the absence of buyer power, the effect of shocks is common at all vertical market levels so that the spread is simply determined by marketing costs.

Lloyd et al. (2009) have developed a model of price transmission in a two-level (i.e. retail and farm-gate) vertical market that explicitly allows for shocks in both the demand and supply functions for a food product. The theoretical framework delivers an equation for the determination of the price spread in which the impact of these shocks appears with definite sign in the presence of oligopsony power. This provides the theoretical basis for a simple empirical test of the presence or otherwise of perfect competition. Writing the margin equation in unrestricted form (i.e. in terms of prices), an empirical testable equation given by Lloyd et al. (2009) is following:

$$
R=\beta_{0}+\beta_{1} P+\beta_{2} M+\beta_{3} D+\beta_{4} S
$$

where $\mathrm{R}$ is the retail price and $\mathrm{P}$ is the producer price of the good under consideration, $\mathrm{M}$ is a composite variable that represents all other costs that affect the retail-farm price margin, $\mathrm{D}$ is a general demand shifter, and $\mathrm{S}$ is the exogenous shifter in the farm supply equation. The expected signs for the coefficients are $\beta_{1}>0, \beta_{2}>0$ irrespective of the degree of retail competition. The test for the rejection of perfect competition is whether the coefficients on the remaining variables in the retail-producer spread equation are statistically significant.

In the empirical section, it is assumed that the data may be approximated by a VAR (p) model,

$$
X_{t}=\psi_{1} X_{t-1}+\cdots+\psi_{2} X_{t-2}+\cdots+\psi_{m} \ln X_{t-m}+\Phi D_{t}+v_{t}
$$


where $x_{t}$ is a $(k \times 1)$ vector of jointly determined $I(1)$ variables, $D_{t}$ is a $(d \times 1)$ vector of deterministic terms (constants, trends and centred seasonals) and each i $\Phi(\mathrm{i}=1, \mathrm{~K}, \mathrm{p})$ and each $\psi(\mathrm{I}=1, \ldots, \mathrm{m}) \Phi$ are $(\mathrm{k} \times \mathrm{k})$ and $(\mathrm{k} \times \mathrm{d})$ matrices of coefficients to be estimated using a $(\mathrm{t}=1, \ldots \mathrm{T})$ sample of data. $\varepsilon_{\mathrm{t}}$ is a $(\mathrm{k} \times 1)$ vector of n.i.d. disturbances with zero mean and non-diagonal covariance matrix, $\Sigma$.

The presence of a price transmission relationship between retailer and producer is indicated by the detection of cointegration among the variables in $\mathrm{x}_{\mathrm{t}}$. Rearranging (2) into its error correction form,

$$
\Delta X_{t}=\alpha \beta^{\prime} X_{t-m}+\sum \Gamma_{i} \Delta X_{t-1}+\Phi D_{t}+v_{t}
$$

we test for cointegration using Johansens's (1988) maximum likelihood procedure in which attention focuses on the $(\mathrm{k} \times \mathrm{r})$ matrix of co-integrating vectors, comprising $\beta$, that quantify the 'longrun' (or equilibrium) relationships between the variables in the system and the $(\mathrm{k} \times \mathrm{r})$ matrix of error correction coefficients, $\alpha$, the elements of which load deviations from equilibrium (i.e. $\beta^{\prime} x_{t-m}$ ) into $\Delta \mathrm{x}_{\mathrm{t}}$, for correction. The $\Gamma_{\mathrm{i}}$ coefficients in (3) estimate the short-run effect of shocks on $\Delta \mathrm{x}_{\mathrm{t}}$, and thereby allow the short and long-run responses to differ.

Where a single cointegrating relationship is detected between retail and producer prices, formal testing of the significance of the supply and demands shocks is undertaken to investigate whether buyer power is present. If the vertical market for a product is perfectly competitive, retail and producer prices may be expected to form a cointegrated relationship with at most marketing costs. Where retailers exert buying power, the supply and demand shifters also enter the pricing relationship. This then gives rise to a null hypothesis of perfect competition which can be evaluated empirically by a standard likelihood ratio test of the exclusion restrictions on the shifters in the cointegrating relation.

In addition, given that the theoretical model signs the parameters in the pricing relation (1), we can offer some additional evidence on the possible rejection of perfect competition by comparing the estimated signs of the shifters in the cointegrating relation with that predicted by the theoretical model.

\section{Data}

We apply test method by Lloyd et al. (2009) to assess whether we can reject perfect competition in Finnish food retailing using widely available market level data on food price indices at retail $(\mathrm{R})$ and producer $(\mathrm{P})$ levels. The price index series are plotted in Figure 1. The data sample begins in January 1995 and runs until September 2009 (giving 177 monthly observations). Measures of marketing costs are not available and thus given the importance of labour costs in food retailing we use an index (base year 1995) of real average earnings in the Finnish service sector (M) to proxy for these costs. To incorporate the impact of farm-level production costs the supply shifter (S) represents a real price index (base year 1995) of all goods and services purchased on Finnish farms. Demand-side shocks is proxied by general consumer price index on the basis that this represents a general demand shifter (D) affecting the retailing sector as a whole. The data is taken from Statistics Finland (2009).

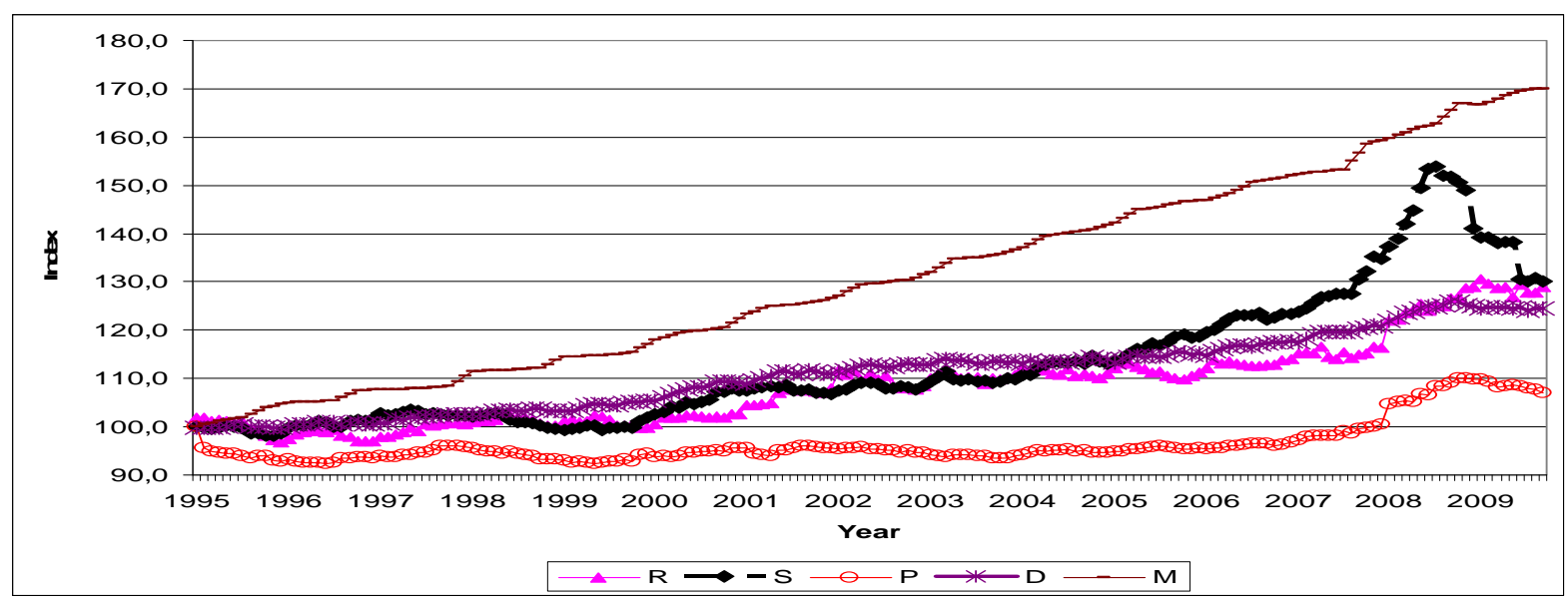

Figure 1. Food price indices at retail (R) and producer (P) levels between 1995-2009. 
Obviously, price index representing producer price has maintained very much in the same level within the sample year, given all other index series have shown a clearly increasing trend over the years, especially among which marketing cost labelled by $\mathrm{M}$ grew the most. This tendency for producer price index and other indices to diverge over time gives rise to a widening in the index spread particularly after year 2002 (See Figure 2).

While growth in the price spread is not in itself indicative of buyer power as marketing cost such as labour cost may be the cause for the phenomenon (Lloyd et. al. 2009). Nevertheless, it is a necessary condition for the existence of buyer power. Thus, further investigation on the existence of buyer power including related factors such as marketing cost should be carefully carried out.

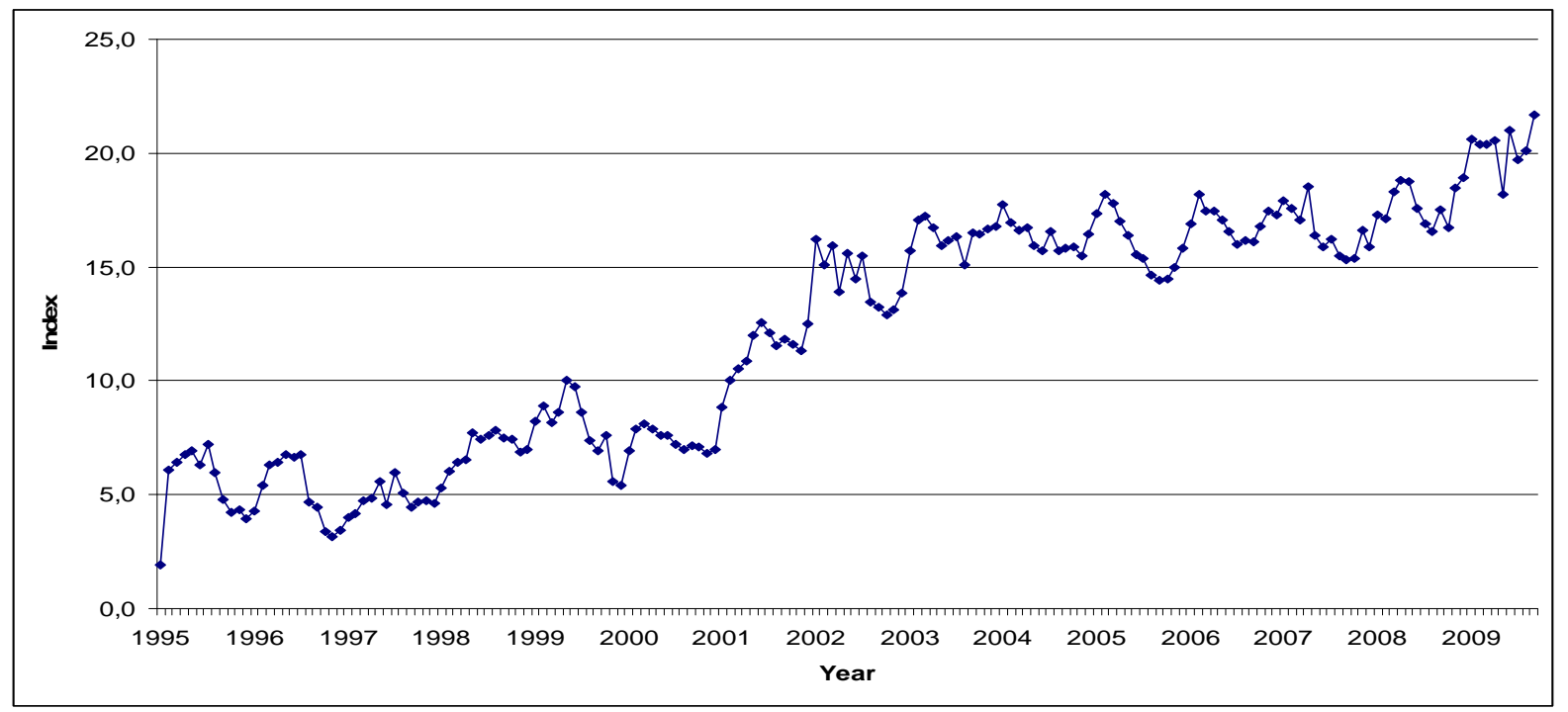

Figure 2: The spread between retail index series and producer index series.

\section{Results}

To decide whether VAR(p) or VECM is proper model for our analysis, we begin with a descriptive analysis of the charateristic of individual prices index series. In other words, we have to examine the stationarity properties of the univariate time series. Stationarity of the price processes are tested using Augmented Dickey-Fuller (ADF) test (1976) and complementary KPSS test ( Kwiatkowski-PhillipsSchmidt-Shin,1992).

Table 1: Test for Cointegration among R, P, M, D and S index series.

(i) Constant included

\begin{tabular}{lllll}
\hline Hypothesized No. of & & & \\
CEs & Max-Eigenvalue & $5 \% \max$ & Trace statistic & 5\% trace \\
\hline $\mathrm{r}=0$ & $44.50^{* *}$ & 33.88 & $83.32^{* *}$ & 69.82 \\
$\mathrm{r}=1$ & 23.56 & 27.58 & 38.82 & 47.86 \\
$\mathrm{r}=2$ & 9.07 & 21.13 & 15.26 & 29.80 \\
$\mathrm{r}=3$ & 4.98 & 14.26 & 6.19 & 15.49 \\
$\mathrm{r}=4$ & 1.21 & 3.84 & 1.21 & 3.84 \\
\hline
\end{tabular}

(ii) Constant and linear trend included

\begin{tabular}{lllll}
\hline Hypothesized No. of & & & \\
CEs & Max-Eigenvalue & $5 \% \max$ & Trace statistic & $5 \%$ trace \\
\hline $\mathrm{r}=0$ & $44.69^{* *}$ & 38.33 & $94.34^{* *}$ & 88.80 \\
$\mathrm{r}=1$ & 28.06 & 32.12 & 49.64 & 63.88 \\
$\mathrm{r}=2$ & 11.22 & 25.82 & 21.57 & 42.92 \\
$\mathrm{r}=3$ & 6.44 & 19.39 & 10.36 & 25.87 \\
$\mathrm{r}=5$ & 3.92 & 12.52 & 3.92 & 12.52 \\
\hline
\end{tabular}

Note: Critical values based on MacKinnon-Haug-Michelis (1999) **denotes rejection of hypothesis at 5\% level 
All the test of unit root test in level form indicates that all of the index series restricted on intercept are non-stationary, and further test on the first difference shows stationarity ${ }^{1}$, which suggest that the index series are I(1) with either intercept or with intercept and trend.

Given that the data are all integrated in first order, we now analyze the price transmission between retailing price and producer supply price by VECM model defined by equation (3). Thus the second step of our analysis is to test the cointegration relationship among the index series.

The result of Johanson cointegration test is presented in Table 1. The Akaike Information is used to determine the optimal order of lags ( 3 lags for each series). Both trace statistics and Maxeigenvalue indicate that a single cointegrating vector $(\mathrm{r}=1)$ is found significant, whether or not the linear trend restriction included. Further, under sequential testing, the first rejection failure occurs while using the model without trend and, thus, we accept the model without trend as appropriate. We further check the cointegrating residuals for autocorrelation and trending test, and the results appear to be satisfactory.

Next, Table 2 reports the parameters of the cointegrating vectors normalised on retail price index obtained from model 3 . The result shows that $\beta_{1}>0$, and $\beta_{2}>0$, which is in accordance with the theoretical model 1 . However, it is noteworthy that the parameter of coefficient of $M$ representing marketing cost shows statistically insignificance. This implies that labour cost alone may not serve the best proxy as a general marketing cost variable. In addition, the signs for the existence of buyer power $\beta_{3}$ and $\beta_{4}$ turn positive and negative respectively, which is correctly signed according to the predictions in the theoretical model. However, the estimated coefficient of supply shifter index S appears to be insignificant. In order to obtain more precise statistical significance of coefficients $\mathrm{S}$ and $\mathrm{D}$, we further perform a set of likelihood ratio tests.

Table 2. Estimated cointegrating vectors (normalised on retail price index).

\begin{tabular}{lll}
\hline Index proxies & Parameters & Values \\
\hline Producer price index (P) & $\beta_{1}$ & $0.65^{* * *(0.16)}$ \\
Marketing cost (M) & $\beta_{2}$ & $0.09(0.07)$ \\
Demand shifter index (D) & $\beta_{3}$ & $0.68^{* * *}(0.16)$ \\
Supply shifter index (S) & $\beta_{4}$ & $-0.03(0.08)$ \\
\hline
\end{tabular}

The results is displayed in Table 3, and clearly the null hypothesis of the perfect competition $\beta_{3}=\beta_{4}=0$ is rejected between producer and retailing prices. Meanwhile, we merely note that though $\beta_{4}=0$ cannot be rejected, but it is correctly signed according to the theoretical model. Therefore, overall the results suggest that the spread between producer and retailer prices is not consistent with perfectly competitive behaviour and thus might be caused by, at least as a candidate amongst other factors, the existence of oligopsony power in Finnish food retailing.

Table 3. Test results for competition.

\begin{tabular}{l|l}
\hline Hypotheses & Values \\
\hline$H_{0}: \beta_{3}=0$ & $10.02^{* * *}[0.002]$ \\
$H_{0}: \beta_{4}=0$ & $0.13[0.71]$ \\
$H_{0}: \beta_{3}=\beta_{4}=0$ & $11.12^{* * *[0.00]}$ \\
\hline
\end{tabular}

\section{Conclusions}

In this paper, we have applied the test method by Lloyd et al. (2009) to test the presence of buyer power in vertically-related Finnish food markets. As explained by Lloyd et al. (2009) the approach is simple and transparent yet delivers a statistical test derived from a theoretically-consistent basis. Furthermore, the test demands relatively little in terms of data and is implemented using standard techniques of modern time-series analysis.

Drawing on data on price indices at retail $(\mathrm{R})$ and producer $(\mathrm{P})$ levels, we showed that the hypothesis of perfect competition can be rejected, implying that the Finnish market is characterised by

\footnotetext{
${ }^{1}$ The unit root test results on the first difference are not reported but are available upon request.
} 
buyer power by the Lloyd's et al. (2009) measure. Of course, the result cannot be interpreted as being conclusive of the use of buyer power in Finnish food retailing. Clearly, econometric tests of the sort have limitations. Data is subject to measurement problems, particularly regarding the quality of proxies that are available to account for changes in sector-specific marketing costs (demand and supply shocks) are not to be taken lightly. It should also be stressed that the test does not allow the degree or economic significance of market power to be measured, merely whether it exists.

However, the Lloyd's et al. (2009) method is both familiar to applied economists and readily implemented, and delivers a 'first pass' test that when used in combination with other evidential indicators, can be useful in contributing to uncovering the existence of buyer power in the vertical food chain.

\section{Kirjallisuus}

Binkley, J. \& Connor, J. 1998. Grocery market pricing and the new competitive environment. Journal of Retailing 74: 273-294.

Binkley, J., Canning, P., Dooley, R. \& Eales, J. 2002. Consolidated markets, brand competition, and orange juice prices. U.S. Department of Agriculture, Agriculture Information Bulletin No. 747-06. Washington D.C.

Cotterill, R. 1986. Market power in the retail food industry: Evidence from Vermont. Review of Economics and Statistics 68: 379-386.

Cotterill, R. 1999. Continuing concentration in food industries globally: Strategic challenges to an unstable status quo. Food Marketing Policy Research Center, research report 49, University of Connecticut.

Cotterill, R. \& Harper, C. 1995. Market power and the Demsetz quality critique: An evaluation for food retailing. Food Marketing Policy Research Center, research report 29, University of Connecticut.

Dobson, P., Waterson, M. \& Davies, S. 2003. The patterns and implications of increasing concentration in European food retailing. Journal of Agricultural Economics 54: 111-125.

Hall, L., Schmitz, A., \& Cothern, J. 1979. Beef wholesale-retail marketing margins and concentration. Econometrica 46: 195-200.

Kaufman, P. \& Handy, C. 1989. Supermarket prices and price differences: City, firm, and sore-level determinants. U.S. Department of Agriculture, Economic Research Service, Technical Bulletin No.1776. Washington D.C., 29 p.

Kuosmanen, T. \& Niemi, J. 2009. What explains the widening gap between the retail and producer prices of food? Agricultural and Food Science 18: 317-331.

Kuosmanen, T., Niemi, J. \& Sipiläinen, T. 2009. Maataloustuen ja tuottavuuden vaikutukset elintarvikkeiden hintamarginaaleihin ja hinnanmuodostukseen (in Finnish), MTT Kasvu 3, Jokioinen, 49 p.

Lloyd, T., McCorriston, S., Morgan, W., Rayner, A. \& Weldegebriel, H. 2009. Buyer power in U.K. food retailing: A 'first-pass' test. Journal of Agricultural \& Food Industrial Organization 7: 1-37.

Niemi, J. \& Ahlstedt J. (eds.) 2009. Finnish agriculture and rural industries 2009. MTT Agrifood Research Finland, Economic Research, publications 109a. 96 p.

Statistics Finland 2009. Consumer price statistics, Producer price statistics, Input price statistics. Available at www.stat.fi

Swinnen, J. \& Vandeplas, A. 2009. Market power and rents in global supply chains. A paper presented in the $27^{\text {th }}$ Conference of International Association of Agricultural Economists, 16-22 August 2009, Beijing, China.

Wohlgenant M. 2001. Marketing margins: Empirical analysis. In: Gardner B. \& Rausser G. (eds.). Handbook of agricultural economics, Vol. 1B, Amsterdam: North Holland, p. 933-970. 